\title{
Floating beds - \\ a flexible bed-management-system in a Swiss acute hospital
}

\author{
N. S. Baschung, M. Henz, T. E. Ruppli \\ Basle Institute of Technology and Management, A University of \\ Applied Sciences, CIM Centre Muttenz,St. Jakobs-Strasse 84, \\ CH-4132 Muttenz, Switzerland \\ Tel: +41614674343 \\ Fax: +41614674461 \\ e-mail:bmd-team@fhbb.ch
}

\begin{abstract}
This paper describes a project which achieved a completely new method of bedmanagement in a Swiss acute hospital. Thanks to a flexible system, which means that the beds are not allocated exclusively to single clinic departments but according to the needs of each department, an enhancement on different levels could be attained. The new system is patient-friendly, improves the co-operation within the hospital and enables a transparent cost accounting.
\end{abstract}

\section{Keywords}

County medical centre, design of business processes, flexible bed-managementsystem, hospital, modelling, process reengineering, reorganisation, simulation.

\section{INTRODUCTION}

Due to new laws and the increasing costs in health care it became vital to react and to adapt the entire health sector to the new challenges. New methods and approaches have to be found.

The management of the Kantonsspital Bruderholz (KSB), a county medical centre with different clinic departments (General Surgery, Orthopaedic Surgery, Obstetrics and Gynaecology, Internal Medicine, Rehabilitation) and over 500 beds, decided to introduce a new method of the bed-management called "Floating Beds". 


\section{PROJECT DESCRIPTION}

The main idea of "Floating Beds" is to establish a new system that enables a free bed allocation. So far, each clinic department had their allocated number of beds.

First of all, it must be said that $50 \%$ of the patients are emergencies, therefore planning of in-hospital stay's is difficult. Secondly, experience has shown that once a clinic department was fully occupied, the staff never knew where to place additional patients. One of the possibilities was to put them in another department until they could be moved to the department they belong to. This caused many inconveniences to patients, nursing staff and of course a lot of paperwork was necessary. Another point was that in such periods there was no guarantee that patients could be placed according to the insurance class they were insured for (one-bed room, two-bed room, four-bed room). Therefore, our idea was to establish a system which enables a flexible bed-management, meaning that individual clinic departments only have the minimum of fixed beds and that the other beds are shared between the different departments. With this new system each clinic department is able to absorb their peaks. This is a completely new approach for a county hospital and found therefore much acclaim in the press.

Another target of "Floating Beds" was to enable a fair cost accounting. This was achieved by considering the number of patients treated in each clinic as the most important dimension and not as previously the allocated number of beds. The Kantonsspital Bruderholz is the first acute hospital in Switzerland with such a flexible bed-management-system.

The "Floating Beds" project is the reason why the Swiss magazine "Beobachter" has chosen this county medical centre as one of the fourteen most innovative hospitals in Switzerland.

\section{SIMULATION}

One of the main problems was to define the optimal size (number of beds) of each department. For such a logical, complex and dynamic system (i.e. many different conditions) simulation was the best instrument to obtain an optimal result in a very short time.

For this reason the software MASTER (Muttenzer Assistant for Simulation Tasks with Expert Reasoning) was used. MASTER is a composite simulation environment under development at Basle Institute of Technology and Management. It allows experienced, occasional or even inexperienced users to perform efficient simulation studies. In order to achieve this aim its architecture combines in parallel a powerful general-purpose simulation language (SIMSCRIPT), along with knowledge-based modules developed with KEE system and also spread-sheet modules developed in LOTUS-123. The main 
function of the knowledge-based modules is to provide ease of use (without modelling flexibility) and to promote the user's potentiality.

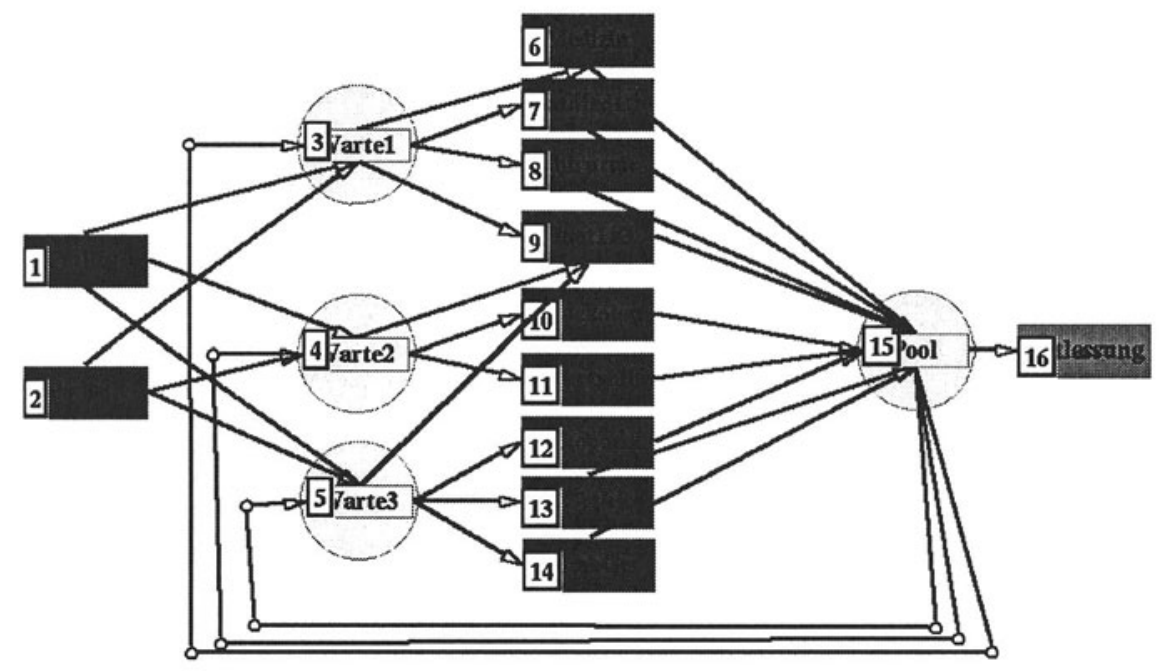

Figure 1 Process network of the "Floating Beds" model

In order to obtain an exact result for the "Floating Beds" project, three different models were developed and tested in various simulations, each based on data of the year 1996. Of course, the team also had to consider the future situation in the Swiss health sector.

With the help of simulation tools the weak points in the old clinic-system were discovered and the dimension of each clinic, using fix and flexible beds, could be roughly determined.

However, other aspects, such as the views of physicians, the nursing staff and structural basic condition, had to be taken into consideration. An important point was also that the project core team always informed the staff concerned during each project phase, because the organisation with the new concept "Floating Beds" is not the same as it was before. 


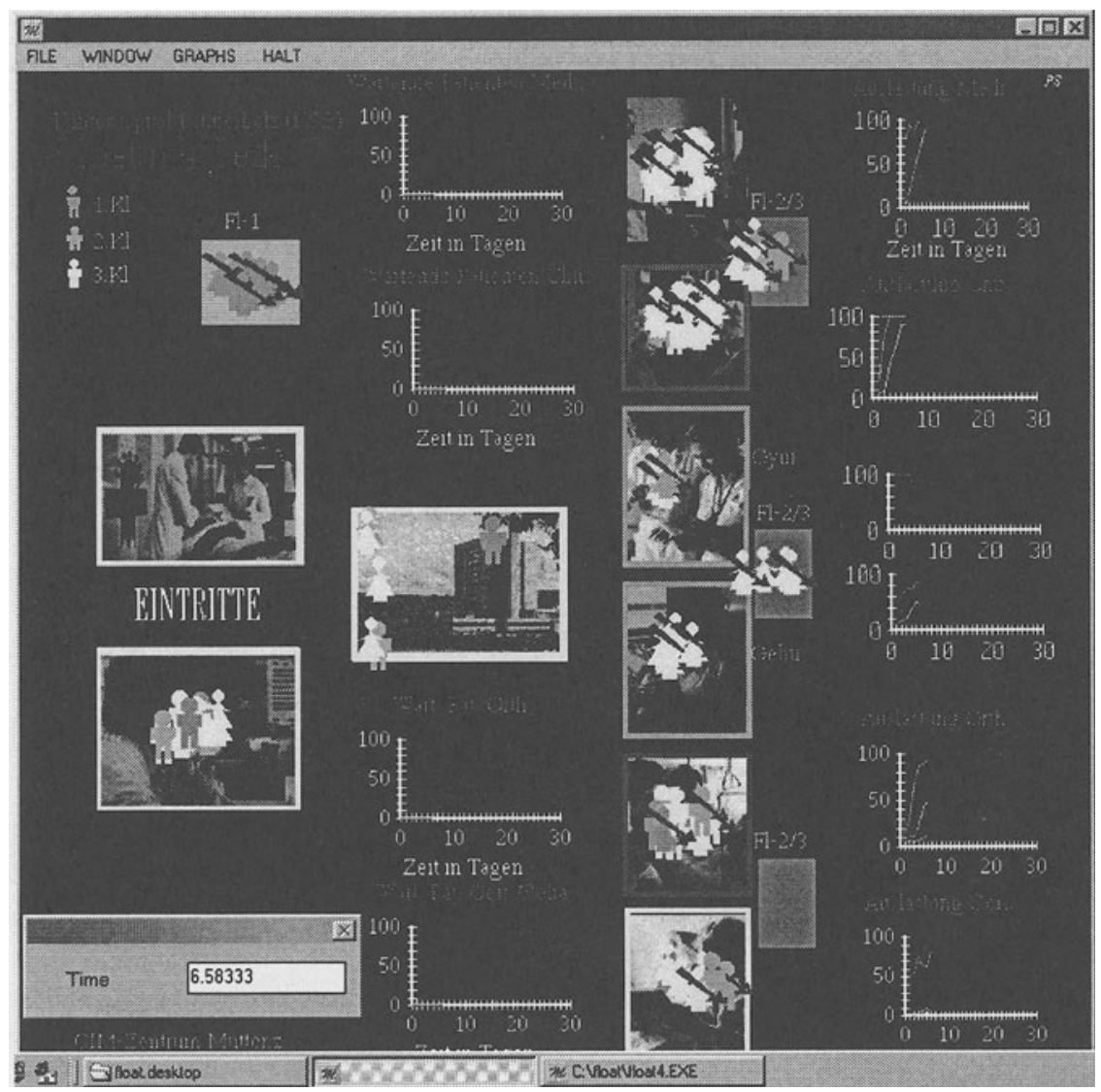

Figure 2 Screenprint of the simulation model

\section{CONCLUSION}

Now the "Floating Beds" project has been working for one year and it can already be concluded that the new system is very successful. The collaborators concerned in all sectors agree that this concept will win through in other hospitals. 
The advantages of the "Floating Bed" concept are varied:

Table 1 Comparison between the old and the new "Floating Beds" system

\begin{tabular}{|c|c|c|}
\hline & old & new \\
\hline Resources & $\begin{array}{l}\text { - Beds are fix allocated to } \\
\text { the clinics (physicians) }\end{array}$ & $\begin{array}{l}\text { - } \\
\text { Flexible ( floating) } \\
\text { - Existing resources can } \\
\text { be used much more } \\
\text { efficiently }\end{array}$ \\
\hline Co-operation & $\begin{array}{ll}\text { Very complicated and } \\
\text { depending organisation }\end{array}$ & $\begin{array}{l}\text { The co-operation } \\
\text { between the different } \\
\text { clinics could be } \\
\text { improved }\end{array}$ \\
\hline Costs & - Hidden costs & - $\quad$ Transparent costs \\
\hline Administration & & $\begin{array}{l}\text { - Administration release } \\
\text { of physicians }\end{array}$ \\
\hline Bed disposition & $\begin{array}{l}\text { Complicated and not } \\
\text { centralised (many people } \\
\text { involved) }\end{array}$ & $\begin{array}{l}\text { Easier and centralised } \\
\text { (just one person } \\
\text { involved) }\end{array}$ \\
\hline Patients & $\begin{array}{l}\text { Not always in the right } \\
\text { nursing class } \\
\text { - Not always in the right } \\
\text { clinic department } \\
\text { Had to move when they } \\
\text { had to change into the } \\
\text { corresponding department } \\
\text { or/and to the responsible } \\
\text { doctor }\end{array}$ & $\begin{array}{l}\text { Always in the right } \\
\text { nursing class } \\
\text { according to their } \\
\text { health insurance } \\
\text { Do not have to move, } \\
\text { which makes the stay } \\
\text { more comfortable (and } \\
\text { reduces the work of } \\
\text { the nursing staff) } \\
\text { - Interdisciplinary } \\
\text { treatment }\end{array}$ \\
\hline Capacity & $\begin{array}{l}\text { Strain can lead to over or } \\
\text { under capacity in the } \\
\text { different clinics }\end{array}$ & $\begin{array}{l}\text { - Strain can be managed } \\
\text { between the different } \\
\text { clinics }\end{array}$ \\
\hline Job & & - Job enrichment \\
\hline
\end{tabular}




\section{PROJECT ORGANISATION}

Trudi Baumann, head of nursing staff, Kantonsspital Bruderholz, Switzerland

PD Dr. Niklaus Friederich, MD, Head Department of Orthopaedic Surgery, Kantonsspital Bruderholz, Switzerland

Martin Henz, research scientist and consultant at Basle Institute of Technology and Management, CIM Centre Muttenz, Switzerland

Thomas Kunz, Chief of the Service Department, Kantonsspital Bruderholz, Switzerland

Thomas Ruppli, sen. lecturer at Basle Institute of Technology and Management, CIM Centre Muttenz, Switzerland

\section{REFERENCES}

Bettoni, M.; Bernhard, W.: Simulation with MASTER - A knowledge-based assistant for speeding up simulation projects, in: Moving Toward Expert Systems Globally in the $21^{\text {st }}$ Century, J. Liebowitz (ed.), Cognizant Communication Corp., New York, 1994

Bernhard W.; Bettoni M.: General Purpose Enterprise Simulation with MASTER; Winter Simulation Conference WSC'93, 12-15 December 1993, Society for Computer Simulation International, Los Angeles, USA.

Harfner, A. Dr.: Spezialisierungs- und Konzentrationsprozesse im deutschen Krankenhauswesen bei einem fallbezogenen Finanzierungssystem - eine quantitative Analyse mit Hilfe computergestützter Szenarienrechnungen, Universität Erlangen-Nürnberg; Dissertation von Anja Harfner, März 1999

Henz, M.: Floating Beds: Beteiligte sprechen über ihre ersten Erfahrungen mit dem neuen System, in: Kantonsspital Bruderholz, Geschäftsbericht 1998

Henz, M.: Floating Beds - Ein halbes Jahr nach der Einführung, in: CZMINFOSTVINFO (Zeitschrift des CIM-Zentrums Muttenz (CZM) und der Sektion Basel des Schweizerischen Technischen Verbandes (STV)), Nr. 18, Dezember 1998

Henz, M.; Ruppli, T.: Floating Beds - Beratungsmandat in einem Schweizer Akutspital, in: Magazin FHBB (Fachhochschule beider Basel), Nr.1/ November 1997

Henz, M.: Floating Beds - Neues Organisationskonzept im Kantonsspital Bruderholz, in: IBB (Ingenieurschule beider Basel) Jahresbericht 1996

Henz, M.; Ruppli, T.: Forschung und Dienstleistung in optimaler Ergänzung, in: IBB News (Ingenieurschule beider Basel), Nr. 11, Dezember 1996

Huwiler, K.: Flexible Bettenbewirtschaftung, Floating Beds, in: Schweizer Spital, Nr. 10/97

Kunz, Th.: Floating Beds, in: KSB-Aktuell, 2/98

Kunz, Th.: Floating Beds-Hintergründe und Ziele, in: KSB-Aktuell, Ausgabe 4/96 
Kunz, Th.; Leutwiler, Th.: Überprüfung der administrativen Abläufe in der Patientenaufnahme, in: KSB-Aktuell , 2/96

Das Bruderholzspital floatet seine Patientenbetten, in: Basler Zeitung, 2. November 1998

Betten fliessen von Klinik zu Klinik, in: Basellandschaftliche Zeitung (BZ), 7. April 1997

Tagesklinik und Floating Beds, in: Basler Zeitung, 4. April 1997

Bruderholz: Floating Beds, in: Basellandschaftliche Zeitung (BZ), 4. April 1997

100 Schweizer Spitäler im Test, in: Beobachter: 11/98

\section{BIOGRAPHY}

Martin Henz, dipl. engineer HTL / STV

Project manager and consultant in different consulting projects, research scientist in several national and international projects and lecturer for project management and process reengineering at Basle Institute of Technology and Management (a University of Applied Sciences), Switzerland. Consulting and research projects within the areas of: business reengineering, process management and process management software (workflow), management in hospitals, enterprise analysis, benchmarking and logistics. Previously worked for several years as a design engineer/mechanical engineer.

Nicole S. Baschung, degree in Business Administration

Research scientist engineering at Basle Institute of Technology and Management. Involved in the following research projects: ENAPS (Establish and test a permanent European Network for Advanced Business Process Performance Studies in European industry); and "Machbarkeitsstudie für eine Wärmepumpe" (Investigate the market chances, the development and production costs of heat pumps with a Stirling motor as substitution for oil and gas heating in small houses). Ms Baschung is also involved in various consulting projects within the areas of controlling, process analysis and marketing. Previously worked for six years in the banking sector in various departments.

Thomas E. Ruppli, MBA University of St. Gallen and dipl. engineer

Sen. Lecturer at Basle Institute of Technology and Management (a University of Applied Sciences), Switzerland. Head of R\&D and head of the Management Development Team at the CIM-Centre Muttenz. Mr. Ruppli is responsible for several national and international research and consulting projects. Previously worked for sixteen years for various industrial and international consulting companies and has run his own consulting company for the past six years. 